\title{
A Rhamnose-Rich 0-Antigen Mediates Adhesion, Virulence, and Host Colonization for the Xylem-Limited Phytopathogen Xylella fastidiosa
}

\author{
Jennifer C. Clifford, Jeannette N. Rapicavoli, and M. Caroline Roper \\ Department of Plant Pathology and Microbiology, University of California, Riverside 92512, U.S.A.
}

Submitted 4 December 2012. Accepted 8 February 2013.

\begin{abstract}
Xylella fastidiosa is a gram-negative, xylem-limited bacterium that causes a lethal disease of grapevine called Pierce's disease. Lipopolysaccharide (LPS) composes approximately $75 \%$ of the outer membrane of gram-negative bacteria and, because it is largely displayed on the cell surface, it mediates interactions between the bacterial cell and its surrounding environment. LPS is composed of a conserved lipid A-core oligosaccharide component and a variable $\mathrm{O}$-antigen portion. By targeting a key $\mathrm{O}$-antigen biosynthetic gene, we demonstrate the contribution of the rhamnose-rich $\mathrm{O}$-antigen to surface attachment, cell-cell aggregation, and biofilm maturation: critical steps for successful infection of the host xylem tissue. Moreover, we have demonstrated that a fully formed $\mathrm{O}$-antigen moiety is an important virulence factor for Pierce's disease development in grape and that depletion of the O-antigen compromises its ability to colonize the host. It has long been speculated that cell-surface polysaccharides play a role in $X$. fastidiosa virulence and this study confirms that LPS is a major virulence factor for this important agricultural pathogen.
\end{abstract}

Xylella fastidiosa is a gram-negative bacterium that causes disease on several economically important crops, including Pierce's disease (PD) of grapevine. This bacterium is transmitted via xylem-feeding insects belonging to the Cicadellidae family, primarily sharpshooters (Janse and Obradaovic 2010). Grapevines infected with this bacterium experience extensive blockage of the xylem vessels. In addition to bacterial cell aggregates, exopolysaccharide (EPS), and host-derived tyloses, it is proposed that host gums and degradation products of the host cell wall also contribute to the occlusions found in the xylem of PD-infected grapevines (Roper et al. 2007a and b). PD symptoms include marginal leaf chlorosis and necrosis, irregular periderm development, leaf blade abscission, and even vine death (Varela et al. 2001). Several bacterial components such as type I pili, hemaglutinnins, and fimbriae have been identified that contribute to $X$. fastidiosa's adhesive characteristics that are necessary for successful colonization of the plant or insect host (Chatterjee et al. 2008; Feil et al. 2007; Guilhabert and Kirkpatrick 2005; Killiny and Almeida 2009; Li et al.

Corresponding author: M. C. Roper; E-mail: mcroper@ucr.edu

Current address of J. C. Clifford: United States Department of Agriculture-Agricultural Research Service Horticultural Crops Research Laboratory, Corvallis, OR 97330, U.S.A.

(C) 2013 The American Phytopathological Society
2007; Newman et al. 2004). However, little is known about the contribution of $X$. fastidiosa's cell-surface polysaccharides to either of these interactions.

Lipopolysaccharide (LPS) composes approximately $75 \%$ of the gram-negative bacterial cell surface, making it the most dominant macromolecule displayed on the cell surface (Caroff and Karibian 2003; Foppen et al. 2010; Madigan 2012 ). LPS plays diverse roles for the bacterial cell. Because of its location in the outer membrane, it is a key contributor to the initial adhesion of the bacterial cell to a surface or host cell (Goldberg and Pler 1996; Walker et al. 2004). It can also play a protective role by acting as a permeability barrier to toxic antimicrobial substances. Additionally, host perception of LPS is well documented and occurs in both plants and animals. Host immune receptors can recognize several regions of the LPS structure and mount a defense response to counteract bacterial invasion. In turn, bacteria can also circumvent the host's immune system by altering the structure of the O-antigen moiety or by masking it with capsular polysaccharide or EPS (Bergman et al. 2006; Guerry et al. 2002; Lerouge and Vanderleyden 2002). Accordingly, LPS has been implicated as a major virulence factor in both plant and animal pathogens such as Escherichia coli, Xanthomonas campestris pv. campestris, and Ralstonia solanacearum (Dow et al. 1995; Hendrick and Sequeira 1984; Muhldorfer and Hacker 1994).

LPS is a tripartite glycolipid is generally composed of highly conserved lipid A, an oligosaccharide core, and a variable O-antigen polysaccharide (Whitfield 1995), the latter of which is the immundominant portion of the molecule. The core oligosaccharide is assembled onto the preformed lipid A molecule that is anchored in the inner membrane, then flipped to the periplasm. Monosaccharides that compose the O-antigen are assembled in the cytoplasm and independently delivered to the periplasm, where it is ligated onto the lipid A/core complex and then translocated to the outer membrane (Raetz and Whitfield 2002; Wang and Quinn 2010). The most widely distributed system for the assembly and translocation of bacterial $\mathrm{O}$-antigen polysaccharides is the Wzy-dependent pathway (Valvano 2003; Whitfield 1995; Whitfield and Larue 2008). Most O-antigens synthesized by the Wzy-dependent pathway are heteropolymers and are composed of repeating subunits referred to as O-units. O-antigen is the most surface-exposed portion of the LPS and can contain as many as 60 repeating O-units that can extend distances more than $30 \mathrm{~nm}$ into the surrounding environment (Ivanov et al. 2011; Kotra et al. 1999; Raetz and Whitfield 2002; Walker et al. 2004). This process is mediated, in part, by the Wzy polymerase, which catalyzes the polymerization of the individual O-units that make up the Oantigen chain. Furthermore, targeted mutations in wzy ortho- 
logs affected virulence in Vibrio vulnificus and Francisella tularensis (Kim et al. 2012; Nakhamchik et al. 2007).

In silico analysis identified a $w z y$ ortholog (PD0814) in the Xylella fastidiosa genome predicted to encode a Wzy polymerase. In this study, we demonstrate that Wzy is necessary for biosynthesis of a high molecular weight O-antigen in $\mathrm{X}$. fastidiosa by facilitating the addition of rhamnose-rich O-units to the polymer. Furthermore, we show that the O-antigen plays a key role in mediating the adhesive properties of the cell which, in turn, affects its ability to successfully colonize and cause disease in the grapevine host.

\section{RESULTS}

\section{Protein domain analysis of Wzy.}

PD0814 is a $w z y$ ortholog with similarity to an O-antigen polymerase from Xanthomonas campestris pv. raphani $(52 \%$ similarity with $93 \%$ coverage, $E$ value $=2 \mathrm{e}-104)($ Bogdanove et al. 2011). The genomic context implies a role in LPS biosynthesis as well (Fig. 1A). The protein encoded by PD0814 is structurally similar to other Wzy proteins and contains a conserved Wzy_C domain involved in synthesis of O-antigens (clusters of orthologous groups [COG3307], Interpro [IPR007016], and Pfam [Pfam04932]) in amino acid residues 255 to 338 (Fig. 1B). Proteins in the Wzy_C family have similar protein structure, based largely on the presence of several transmembrane domains, despite dissimilarity in primary sequence to characterized homologs. According to protein prediction based on the Joint Genome Institute website, hydropathy plot analysis (data not shown), and online software (Rost et al. 2003), PD0814 is predicted to have 10 transmembrane domains; having several transmembrane domains is characteristic of the Wzy_C family of proteins (Fig. 1B).

The structure of the Pseudomonas aeruginosa Wzy polymerase has been elucidated and consists of 14 membranespanning domains, with 4 periplasmic and 2 cytoplasmic loops

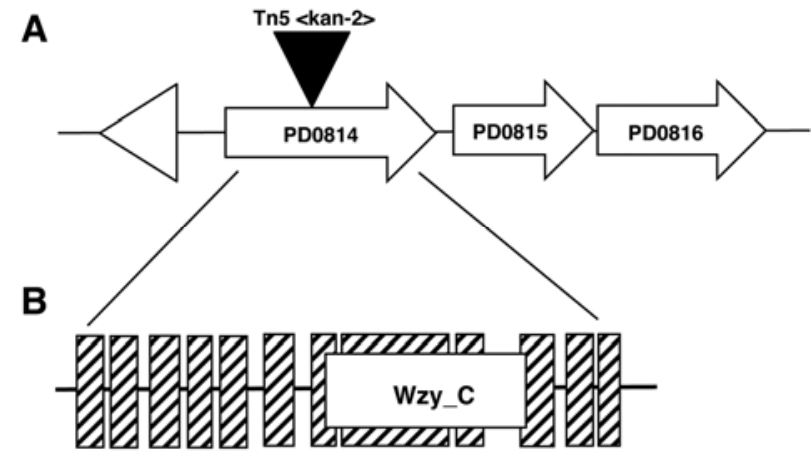

Fig. 1. Genomic context of PD0814 and its predicted protein structure. A, PD0814 is located in the same region as waaE (PD0815), a gene predicted to encode an lipopolysaccharide core biosynthesis glycosyl transferase, and PD0816, predicted to encode a glycerophosphotransferase family protein. B, Predicted protein structure of PD0814, Wzy, an O-antigen polymerase. There are at least 10 transmembrane domains and a Wzy_C motif spanning amino acids 255 to 338 . The predicted Wzy_C domain is represented by the white rectangle. The hatch-marked boxes represent the transmembrane domains of the predicted Wzy protein.
(Islam et al. 2010). The two periplasmic domains contain the polymerase motif $\mathrm{RX}_{10} \mathrm{G}$, believed to play a role in $\mathrm{O}$-antigen subunit recognition. Xylella fastidiosa PD0814 contains several of these $\mathrm{RX}_{10} \mathrm{G}$ motifs but only two appear to be completely within a periplasmic loop.

\section{A mutation in wzy affects accumulation} of a high molecular weight $\mathrm{O}$-antigen.

The O-antigen of the wild-type strain is primarily a diffuse high molecular weight polymer, as indicated by Tricine-polyacrylamide gel electrophoresis (PAGE) analysis (Fig. 2). These results are similar to the diffuse LPS profiles observed for Xanthomonas campestris pv. campestris and Stenotrophomonas maltophila (Huang et al. 2006; Koplin et al. 1993). We did not observe the laddering pattern typically seen for other bacteria, indicating that the Xylella fastidiosa O-antigen is composed predominantly of chain-length modalities of similar size. The presence of the high molecular weight $\mathrm{O}$-antigen moiety is strikingly diminished in the wzy mutant. Introduction of the wild-type wzy locus into the chromosome of the wzy mutant strain restored the production of the high molecular weight $\mathrm{O}$-antigen observed in the wild type.

\section{A mutation in wzy affects the incorporation of rhamnose into the $\mathrm{O}$-antigen polysaccharide.}

Carbohydrate composition and linkage analysis revealed that the wild-type O-antigen is a heteropolymer consisting mostly of rhamnose and glucose, with smaller amounts of ribose, xylose, and mannose (Table 1). X. fastidiosa is not unique with regards to possessing a rhamnose-rich $\mathrm{O}$-antigen.

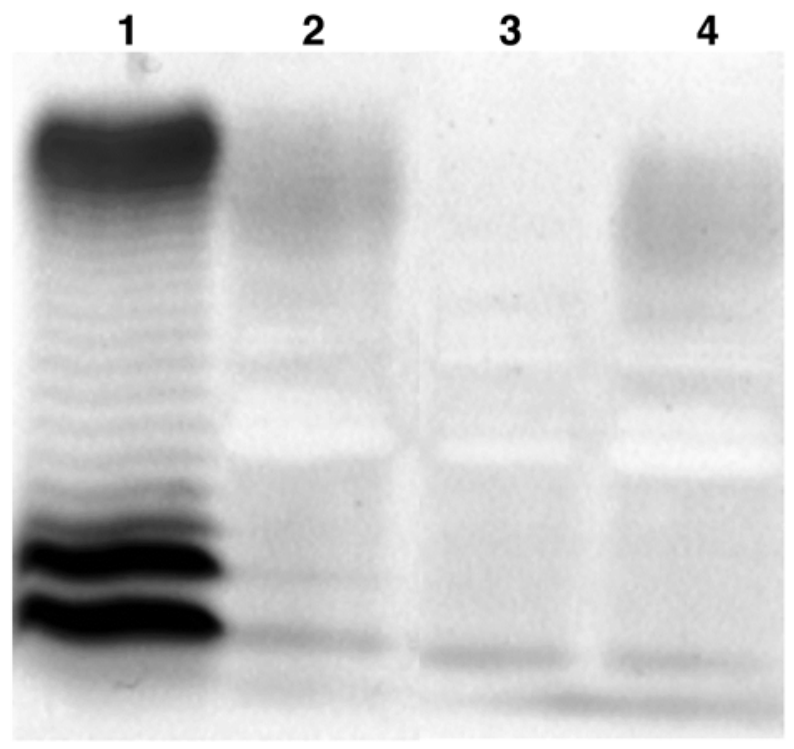

Fig. 2. Lipopolysaccharide (LPS) profiles of Xylella fastidiosa wild-type, wzy mutant, and $w z y / w z y+$ complemented strains. Purified LPS analyzed on a discontinuous $12 \%$ Tricine-polyacrylamide electrophoretic gel demonstrated that the majority of O-antigen was composed of diffuse longchain moieties. The wzy mutant strain is significantly impaired in production of the O-antigen component of LPS. Lane 1, Escherichia coli (SigmaAldrich, St. Louis); lane 2, wild type; lane 3, wzy; lane 4, wzy/wzy+.

Table 1. Glycosyl composition analysis of O-antigen isolated from the wild type or the wzy mutant

\begin{tabular}{lccccc}
\hline & \multicolumn{5}{c}{ O-antigen sugars $($ Mol \%) } \\
\cline { 2 - 6 } Strain & Rhamnose & Glucose & Ribose & Xylose & Mannose \\
\hline Wild type & 68.2 & 19.0 & 6.5 & 5.5 & 0.8 \\
$w z y$ & 9.4 & 84.6 & 4.9 & 0.5 & 0.6 \\
\hline
\end{tabular}

${ }^{\text {a }}$ Values are expressed as mole percent of total carbohydrate. 
In fact, several bacterial species, including some phytopathogenic xanthomonads, which are close relatives of $X$. fastidiosa, also possess rhamnose-rich O-antigens (Casabuono et al. 2011; Molinaro et al. 2002; Shashkov et al. 2000).

The wzy mutant $\mathrm{O}$-antigen was similar in carbohydrate composition to the wild type with regard to the residues present in the polysaccharide. However, there was a dramatic depletion in the percentage of rhamnose in the wzy mutant compared with the wild type, which decreased from $68.2 \%$ in the wild type to $9.4 \%$ in the wzy mutant. (Table 1 ).

O-antigens synthesized by the Wzy-dependent pathway are usually branched heteropolymers (Raetz and Whitfield 2002). Structurally, the wild-type O-antigen consists primarily of (2)linked rhamnose $(39.2 \%)$ with some $(2,3)$-linked rhamnose $(14.1 \%)$, indicating the presence of branching side-chains from the central (2)-linked rhamnose backbone. In addition, the wild-type $\mathrm{O}$-antigen includes $0.6 \%$ terminal rhamnose, suggesting that the O-antigen terminates with a rhamnose residue. In other systems, wzy mutants produce an LPS comprising a lipid A-core capped with a single O-unit (Guo et al. 2005; Ivanov et al. 2011; Kim et al. 2012). Deletion of $w z y$ in X. fastidiosa resulted in a truncated $\mathrm{O}$-antigen composed primarily of (4)-linked glucose with much of the (2)-linked rhamnose absent (Table 2). This suggests that the initial O-unit linked to the core LPS is composed primarily of (4)-linked glucose and the remainder of the polymer that extends out into the environment is a rhamnose-rich repeat with branched side chains.

\section{Role of $\mathrm{O}$-antigen in cell-surface attachment and cell-cell aggregation.}

To quantify the contribution of Wzy and the rhamnose-rich Oantigen in cell-surface attachment and cell-cell aggregation, we independently evaluated the ability of the wild-type, wzy, and $w z y / w z y+$ strains to attach to a solid surface as well as to each other. The wzy mutant showed an increase in attachment to a glass surface compared with the wild-type strain, a phenotype that was restored in the wzy/wzy+ complemented strain $(P<$ 0.0001) (Fig. 3A). Following the protocol of Burdman and associates (2000), we used optical density to evaluate the role of $\mathrm{O}$ -

Table 2. Glycosyl linkage analysis of O-antigen isolated from wild-type or the wzy mutant strains as determined by gas chromatography and mass spectrometry

\begin{tabular}{lcc}
\hline & \multicolumn{2}{c}{ Amount present in strains (\%) } \\
\cline { 2 - 3 } Glycosyl residue $^{\mathbf{b}}$ & Wild type & $\boldsymbol{w z y}$ \\
\hline t-rha & 0.6 & $\mathrm{ND}$ \\
t-xyl & 0.8 & $\mathrm{ND}$ \\
2-ribf & 0.7 & 0.3 \\
2-rha & $\mathbf{3 9 . 2}$ & $\mathbf{5 . 4}$ \\
3-rha, t-man, and 4-rha & 2.7 & 0.8 \\
t-glc & 0.8 & 2.4 \\
4-xyl & 0.3 & 0.3 \\
2,3-rha & 14.1 & 1.8 \\
2- and 3-man & 1.3 \\
2-glc & 2.9 & 0.4 \\
4-man & 0.7 & 2.4 \\
4-glc & 2.2 & $\mathbf{7 6 . 4}$ \\
3,4-glc & $\mathbf{3 3 . 6}$ & 4.9 \\
2,4-glc & 0.9 & 0.4 \\
2,3,4-xyl & 0.1 & 0.4 \\
4,6-glc & 0.2 & 2.8 \\
\hline
\end{tabular}

${ }^{a}$ Values represent percentage of total sugar moieties comprising O-antigen; ND = not determined. Values in bold represent the most abundant residue in that strain.

b Abbreviations: t-, 2-, 3-, and 4- = terminal-, 2-, 3-, and 4-linked, respectively; rha $=$ rhamnopyranosyl; $\mathrm{xyl}=$ xylopyranosyl; ribf $=$ ribofuranosyl; $\operatorname{man}=$ mannopyranosyl; and glc = glucopyranosyl

c The majority of this linkage is composed of 3-man. antigen in facilitating cell-cell aggregation. The ability of wzy mutant cells to aggregate to each other was significantly reduced compared with the wild-type strain, and this phenotype was restored in the complemented strain $(P<0.0001)$ (Fig. 3B).

\section{Depletion of rhamnose}

in the $\mathrm{O}$-antigen polysaccharide affects cell surface charge.

The zeta potential, a measure of surface charge, was quantified for the wild-type, $w z y$, and $w z y / w z y+$ mutant strains grown on solid PD3 medium (Davis et al. 1981) and suspended in 10 $\mathrm{mM} \mathrm{KCl}$ (Walker et al. 2004) The surface of the wzy mutant was notably more negatively charged, as indicated by an average zeta potential measurement of $-27.1 \mathrm{mV}$ compared with the zeta potential of the wild-type strain at $-10.5 \mathrm{mV}$ (Table 3 ). The ionic strength of PD3 medium was estimated to be 85 $\mathrm{mM}$. The zeta potential of a glass microscope slide submerged in the growth medium was estimated to be approximately -12 $\mathrm{mV}$ (Walker et al. 2004).

\section{Modification of the $\mathrm{O}$-antigen affects three-dimensional biofilm architecture.}

Because surface attachment and cell-cell aggregation are important biofilm characteristics, we compared biofilm formation of the wild-type and wzy mutant strains by observing strain colonization and growth on a glass surface using confocal laser-scanning microscopy. Following 4 days of incubation

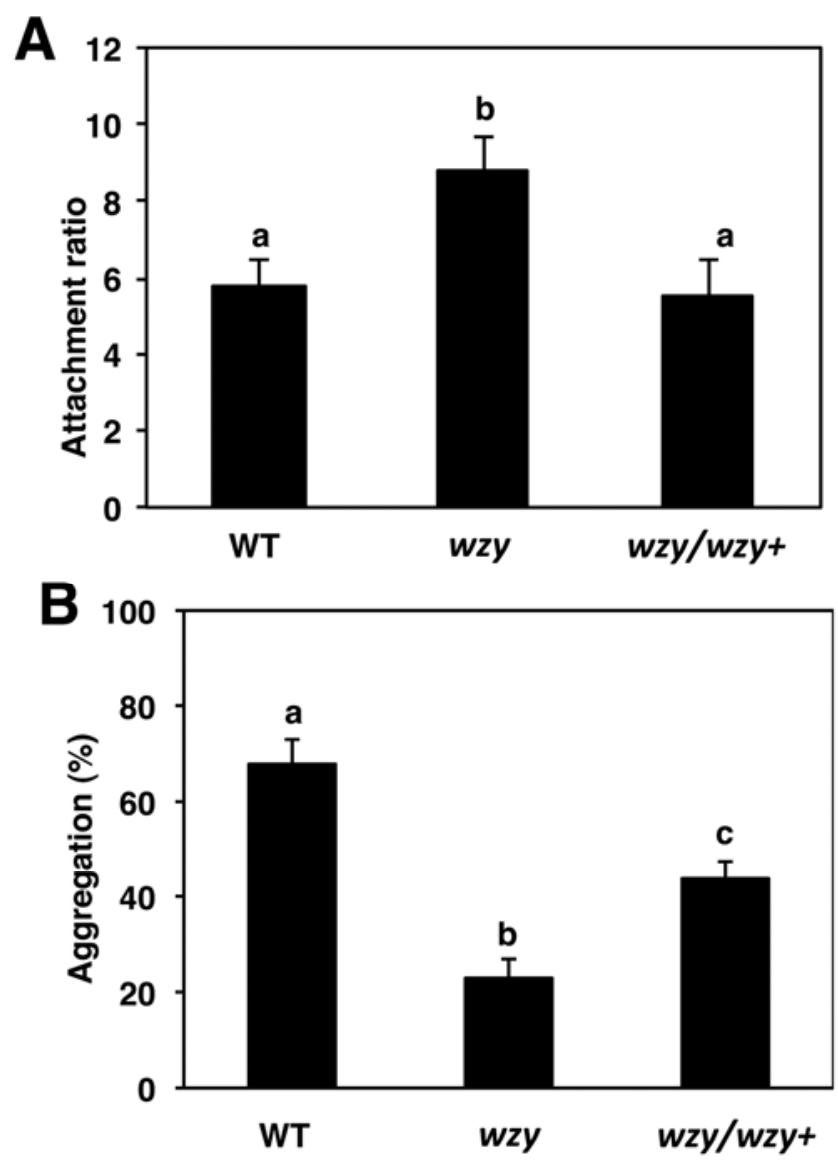

Fig. 3. Contribution of lipopolysaccharide to cell-surface and cell-cell attachment. The wzy mutant $\mathbf{A}$, consistently exhibited greater attachment to a solid glass surface $(P<0.0001)$ and $\mathbf{B}$, was reduced in the ability to form cell-cell aggregates compared with its wild-type (WT) parent or the complemented strain $(P<0.0001)$. Cell-surface attachment was quantified using crystal violet staining as previously described ((Espinosa-Urgel et al. 2000). Cell-cell attachment was quantified by the method of Burdman and associates (2000). At least three independent assays with three replicates were performed. Bars represent the standard error of the mean. 
in PD3 liquid medium, both the wild-type and the wzy mutant strains were capable of attaching to a glass substrate and initiating biofilm formation. However, the wild-type biofilm was significantly thicker $(145 \mu \mathrm{m})$ than the wzy mutant biofilm $(120 \mu \mathrm{m})$ after 4 days, as determined by a Student's $t$ test $(P<$ $0.05)$. Furthermore, the peaks observed for the wzy mutant biofilm were not as homogenously dispersed throughout the biofilm, leading to a rougher biofilm surface compared with the wild type (Fig. 4A and B). Roughness coefficients that take into account biofilm irregularities were calculated according to Piciorneau and associates (2000) and Murga and associates (1995). A lower roughness coefficient indicates a smoother biofilm, whereas a higher roughness coefficient correlates with a rougher biofilm. The roughness coefficients were 0.019 and 0.133 for the wild type and wzy mutant, respectively, and were significantly different based on a Student's $t$ test $(P<0.05)$, indicating that depletion of $\mathrm{O}$-antigen results in a rougher biofilm phenotype. Taken together, the three-dimensional images, biofilm thickness, and roughness coefficients indicate that the wzy mutant is impaired in biofilm maturation.

\section{O-antigen contributes to tolerance \\ of exogenous hydrogen peroxide stress.}

We employed the disk diffusion assay to determine the contribution of a fully formed $\mathrm{O}$-antigen in providing protection against exogenous hydrogen peroxide $\left(\mathrm{H}_{2} \mathrm{O}_{2}\right)$ stress (Matsumoto et al. 2009). The wzy mutant was significantly more sensitive to $100 \mu \mathrm{M} \mathrm{H} \mathrm{H}_{2} \mathrm{O}_{2}$ compared with the wild-type and complemented strains $(P<0.001)$ (Fig. 5).

\section{Absence of Wzy affects virulence and host colonization.}

Grapevines inoculated with the wzy mutant showed significantly less PD symptoms over the course of the virulence study compared with wild-type-inoculated plants. Both strains elicited PD symptoms in the vines after 4 weeks of inoculation; however, plants inoculated with the wzy mutant showed less disease severity. This trend remained constant until the end of the study at week 17, when wild-type-inoculated plants

Table 3. Surface charge of Xylella fastidiosa strains as determined by zeta potential analysis

\begin{tabular}{lc}
\hline Strain & Zeta potential $^{\mathbf{a}}$ \\
\hline Wild type & $-10.5 \pm 2.2$ \\
wzy mutant & $-27.12 \pm 1.91$ \\
wzy $/$ wzy+ & $-10.9 \pm 0.97$
\end{tabular}

${ }^{a}$ Mobility values were determined by electrophoresis and converted to zeta potential. were rated an average of 4.87 compared with the wzy-inoculated plants that were rated an average of $2.22(P<0.0001)$ (Fig. 6A).

To quantify the contribution of O-antigen to host colonization, we performed isolations from grapevine petioles closest to the point of inoculation to quantify bacterial populations within the plant. At 5 weeks postinoculation, we recovered wild-type $X$. fastidiosa from $53 \%$ of vines inoculated with that strain, with a median population size of $8 \times 10^{3} \mathrm{CFU} / \mathrm{g}$ tissue, while no bacterial cells were recovered from petioles harvested from grapevines inoculated with the wzy mutant (data not shown). At 14 weeks postinoculation, $93 \%$ of plants inoculated with wild type were colonized compared with only $40 \%$ of those inoculated with the wzy mutant. The average population of wzy mutant cells recovered from colonized stems was $2.3 \times$ $10^{5} \mathrm{CFU} / \mathrm{g}$ tissue, which was significantly less than wild-type average population of $2.5 \times 10^{7} \mathrm{CFU} / \mathrm{g}$ tissue $(P<0.0001)$ (Fig. 6B).

\section{DISCUSSION}

The lifestyle of $X$. fastidiosa requires colonization of diverse carbohydrate surfaces such as the plant xylem wall and chitin in the mouthparts and foregut of the sharpshooter insect vector. X. fastidiosa forms biofilms or biofilm-like structures in both environments (Newman et al. 2004). During biofilm initiation, only a fraction of the total X. fastidiosa population is producing minute quantities of EPS (Roper et al. 2007a). Therefore, LPS would be the predominantly exposed carbohydrate displayed on the bacterial cell surface, providing the first contact point during the initiation of biofilm development. Indeed, LPS has been implicated in biofilm formation in other bacterial systems, including those associated with plant diseases (Lau et al. 2009; Li and Wang 2011; Yan et al. 2012). Attachment and cell-cell aggregation are important for surface colonization and subsequent microcolony formation, both of which are initial stages in the process of forming a microbial biofilm (Monds and O'Toole 2009; O'Toole et al. 2000). We investigated the role of the O-antigen in these processes in the $X$. fastidiosa system. The ability of an organism to attach to a surface and its aggregative behavior are related to the net charge on the cell (De La Fuente et al. 2008; Ivanov et al. 2011; Vanloosdrecht et al. 1987). Generally, bacterial cell surfaces are negatively charged and the magnitude of this charge depends on cell surface structures, which include LPS (Walker et al. 2004; Wilson et al. 2001). Hence, we hypothesized that modifications to the LPS structure and composition would significantly affect the charge on

Table 4. Bacterial strains and plasmids used in this study

\begin{tabular}{|c|c|c|}
\hline Strain or plasmid & Relevant characteristics $^{\mathrm{a}}$ & Reference, source \\
\hline \multicolumn{3}{|l|}{ Plasmids } \\
\hline $\mathrm{pCR} 8 / \mathrm{GW} / \mathrm{TOPO}$ & Gateway TA cloning vector, $\mathrm{Sp}^{\mathrm{r}}$ & Invitrogen \\
\hline pAXCm1 & pAX1 with cat and multiple cloning site & Matsumoto et al. 2009 \\
\hline pJCC2 & pCR8/GW/TOPO with $2.46 \mathrm{~kb}$ wzy fragment & This study \\
\hline pJCC6 & pJCC2 with wzy::kan-2 & This study \\
\hline $\mathrm{pJCC} 7$ & pCR8/GW/TOPO with $1.84 \mathrm{~kb}$ wzy fragment & This study \\
\hline pJCC8 & pAX1Cm with $1.84 \mathrm{~kb}$ wzy fragment & This study \\
\hline \multicolumn{3}{|l|}{ Xylella fastidiosa } \\
\hline Temecula1 & subsp. fastidiosa, wild-type isolate from grape & Guilhabert et al. 2001 \\
\hline Temwzy (CR68) & Temecula1 with Tn-5 EZ Tn5 , <kan-2> insertion in $w z y, \mathrm{Km}^{\mathrm{r}}$ & This study \\
\hline Temwzy/wzy+(JC11) & $\begin{array}{l}\text { CR68, with } 1.84 \mathrm{~kb} w z y \text { fragment, including promoter, inserted between PD0702/PD0703, NS1:: } \\
\mathrm{Cm}^{\mathrm{r}}, w z y^{+}\end{array}$ & This study \\
\hline \multirow{2}{*}{$\begin{array}{l}\text { Escherichia coli } \\
\text { TOP10 }\end{array}$} & & \\
\hline & 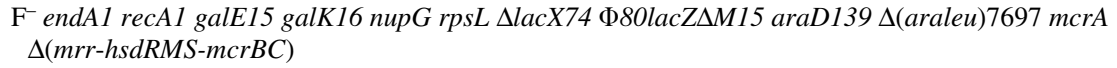 & Invitrogen \\
\hline
\end{tabular}

${ }^{\mathrm{a}} \mathrm{Sp}^{\mathrm{r}}, \mathrm{Km}^{\mathrm{r}}$, and $\mathrm{Cm}^{\mathrm{r}}$ indicate resistance to spectinomycin, kanamycin, and chloramphenicol, respectively. NS1 represents a neutral site, located between the two pseudogenes PD0702 and PD0703 in the X. fastidiosa Temecula1 genome. 
a $X$. fastidiosa cell, which would impact its adherence to a glass surface. Indeed, the wzy mutant was significantly more negatively charged than the wild-type parent and, under the growth conditions tested here, the mutant adhered more strongly to the glass surface than the wild-type strain. This suggests that electrostatic attraction between the extremely negatively charged mutant and the glass is more pronounced than the interaction with the wild type and glass, which are similarly charged. We hypothesize that the long-chain rhamnose-rich portion of the O-antigen acts as an attenuator of surface adhesion for $X$. fastidiosa. A similar phenotype was recently reported where the lack of O-antigen in Rhizobium rhizogenes enhanced adherence to both an abiotic surface and a biotic root-tip surface (Abarca-Grau et al. 2012) and

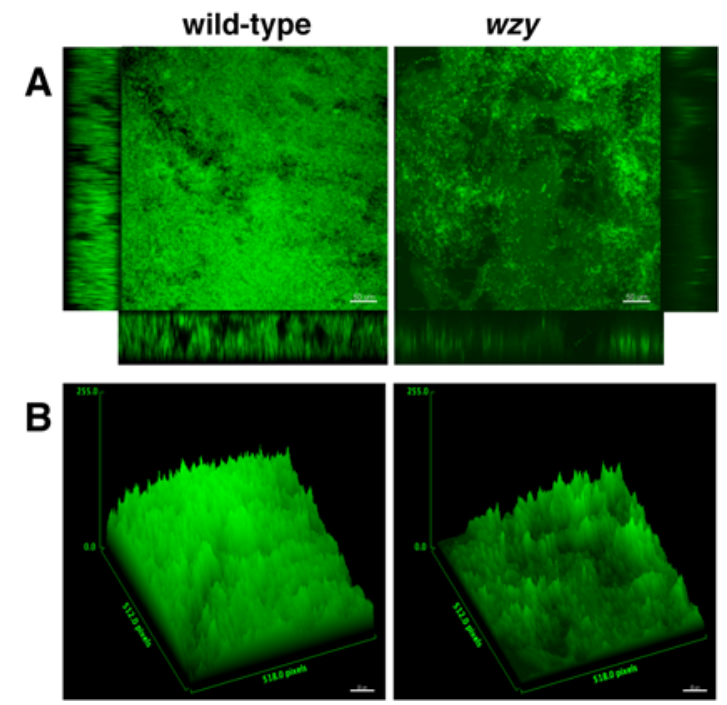

Fig. 4. Biofilm architecture of wild-type, wzy mutant, and complemented strains grown for 4 days on glass slides in PD3 (Davis et al. 1981) broth and visualized using confocal laser-scanning microscopy. The wzy mutant biofilm is thinner in cross section compared with the wild type as a result of the inability to build the peaks associated with wild-type biofilms as observed in $\mathbf{A}$, full view and cross-section images or $\mathbf{B}$, the three-dimensional image.

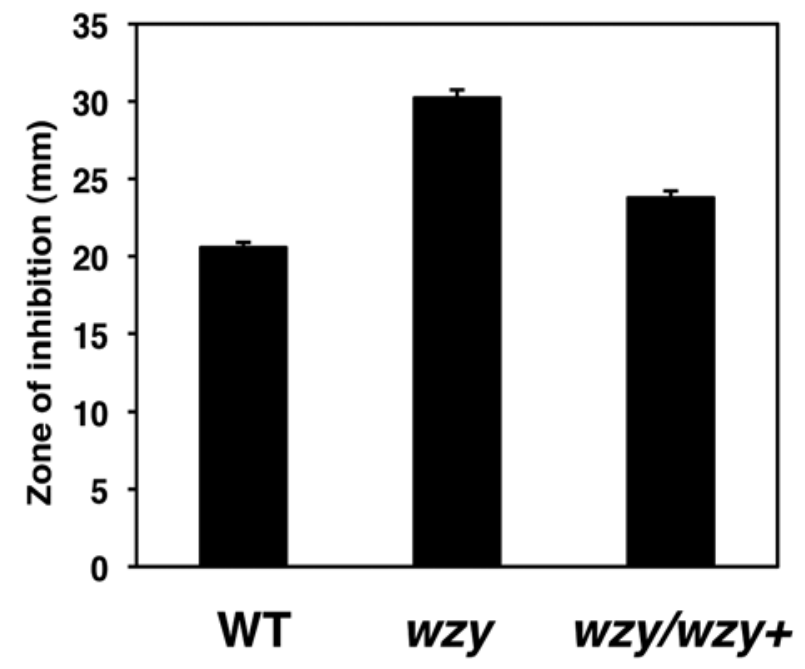

Fig. 5. Lipopolysaccharide protects Xylella fastidiosa against hydrogen peroxide stress. Strains were harvested from solid PD3 medium (Davis et al. 1981) and a disk inhibition assay was performed using $100 \mu \mathrm{M}$ hydrogen peroxide. The wzy mutant was less tolerant to hydrogen peroxide stress than both the wild-type parent or complemented strains $(P<0.0001)$. Three independent assays with three replicates were performed. Bars represent the standard error of the mean. resulted in an increase in attachment of Xanthomonas axonopodis pv. citri (Petrocelli et al. 2012).

It is difficult to estimate the charge of the xylem cell wall due to the heterogeneous distribution of the polysaccharides throughout the cell wall fabric and the fluctuations in xylem sap chemistry over time. However, the polysaccharide components (i.e., pectin, cellulose, and hemicellulose) that make up the xylem primary cell wall are highly hydrophilic and the glass substrate used in the experiments here is also hydrophilic (Tibbets et al. 1998; Zweinicki et al. 2001). This similarity allows us to extrapolate our in vitro results to what might be occurring in portions of the plant xylem tissue that have an abundance of exposed primary cell wall polysaccharides, such as xylem pit membranes. We speculate that production of a rhamnose-rich $\mathrm{O}$-antigen may prevent excessive adherence to the hydrophilic xylem cell wall during the infection cycle. This
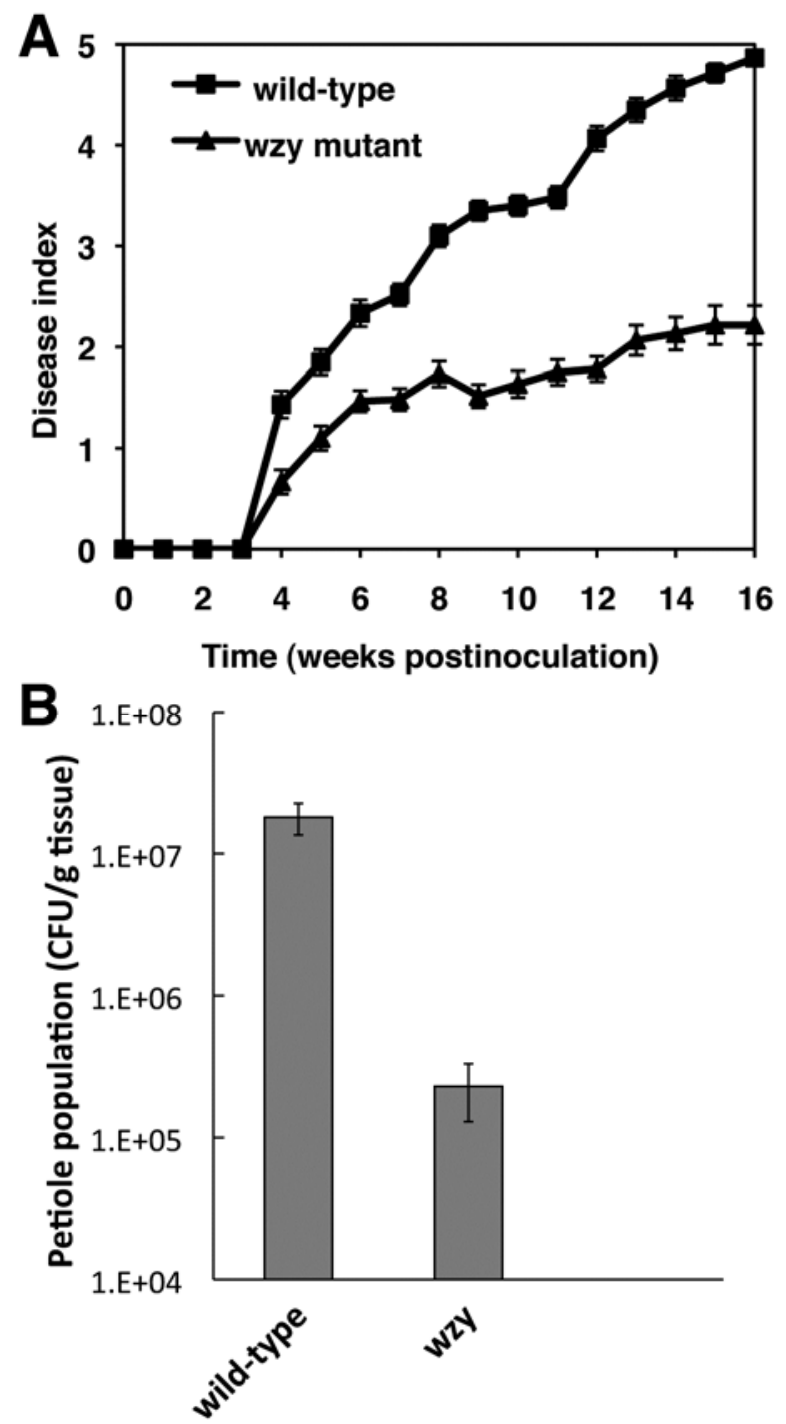

Fig. 6. The O-antigen portion of the Xylella fastidiosa lipopolysaccharide is necessary for Pierce's disease (PD) development on susceptible grapevine. Wild-type and wzy mutant strains were harvested from solid PD3 medium (Davis et al. 1981) and adjusted to an optical density at $600 \mathrm{~nm}=$ 0.25 prior to stem inoculation of 'Thompson Seedless' grapevine. When compared with the wild-type parental strain, the wzy mutant $\mathbf{A}$, caused significantly less PD symptoms $(P<0.0001)$ and $\mathbf{B}$, was reduced in ability to colonize petiole xylem $(P<0.0001)$. For disease progress, the three independent trials were run with 10 plants per trial per strain. For the population studies, five petioles from five different plants were assayed per trial per strain. Bars represent the standard error of the mean. 
would enable the bacterium to move more readily from an occluded vessel to an open vessel that contains a fresh flow of xylem sap and, therefore, a fresh supply of nutrients being carried past it in the xylem sap flow. It is documented that sharpshooter vectors avoid feeding on blocked vessels; therefore, it would be advantageous for the bacterium to have the capacity to move to an open vessel where it would be more likely to be acquired by the insect and transmitted to a new host (Newman et al. 2004).

The three-dimensional biofilm images demonstrated that the wzy mutant biofilms had a difference in spatial distribution of biomass and had more interstitial gaps within the biofilm when compared with the wild type. The wzy mutant was clearly capable of attaching to the glass surface but was unable to build upon itself to create the fully formed pillars characteristic of wild-type $X$. fastidiosa biofilms. This deficiency in pillar formation led to a shorter and rougher biofilm and is likely due to the defect in aggregation, which would prevent the cells from adhering to and stacking upon one another. In addition, particles with lower zeta potentials tend to flocculate or aggregate, which explains the high capacity for wild-type $X$. fastidiosa to aggregate in culture (De La Fuente et al. 2008). However, when particles have a large negative or positive zeta potential, this results in high repulsion among the particles, causing them to resist flocculation. The wzy mutant had a significantly large negative zeta potential $(-27 \mathrm{mV})$ compared with the wild type $(-10 \mathrm{mV})$, likely explaining its impairment in cell-cell aggregation resulting in an overall thinner wzy biofilm. Likewise, mutants in E. coli can be successful in initial attachment but be compromised in downstream steps of biofilm formation (Monds and O'Toole 2009).

However, it is difficult to ascertain whether the change in $\mathrm{O}$ antigen chemistry is directly responsible for the adhesive characteristics of the cell. It is also likely that surface-moleculespecific interactions due to the differing LPS composition are also contributing (Walker et al. 2004). Models based on E. coli $\mathrm{O}$-antigen hypothesize that LPS may be flexible and present in a bent conformation that would mask functional charge groups associated with other cell surface components, such as membrane-bound proteinaceous adhesins (Kastowsky et al. 1992; Walker et al. 2004). X. fastidiosa has several means of attaching to substrata, which include fimbrial and afimbrial adhesins (Caserta et al. 2010; Feil et al. 2007). If X. fastidiosa LPS also adopts a bent conformation, then truncation of the long O-antigen would expose these membrane-associated adhesins, leading to the deviations from the wild type with respect to surface attachment and cell-cell aggregation. Further structural studies of the $X$. fastidiosa $\mathrm{O}$-antigen will reveal any unique epitopes of the rhamnose-containing portion that have such a profound contribution to biofilm-related phenotypes in this pathosystem.

LPS molecules also provide structural integrity to the cell and represent a formidable protection layer that prevents permeability of even very small molecules (Kotra et al. 1999). The O-antigen moiety plays a major role in shielding the cell against antimicrobial compounds (Raetz and Whitfield 2002). We demonstrate here that the $X$. fastidiosa $\mathrm{O}$-antigen does, indeed, protect against exogenous $\mathrm{H}_{2} \mathrm{O}_{2}$ stress, an important environmental stress likely incurred by $X$. fastidiosa as it colonizes the plant. $\mathrm{H}_{2} \mathrm{O}_{2}$ is derived from the oxidative burst associated with the host defense response or from normal plant development processes such as xylem lignification (Apel and Hirt 2004; Hilaire et al. 2001; Lamb and Dixon 1997). This vulnerability may explain, in part, why the wzy mutant was incapable of colonizing the plant xylem to wild-type numbers. The LPS layer likely aids $X$. fastidiosa in protecting itself against $\mathrm{H}_{2} \mathrm{O}_{2}$ and other toxic antimicrobial compounds encountered in the plant and the insect foregut. Similarly, this was shown to be the case in Erwinia amylovora, where a mutant in LPS biosynthesis was reduced in the ability to tolerate $\mathrm{H}_{2} \mathrm{O}_{2}$ stress (Berry et al. 2009).

Contrary to the role of LPS in promoting bacterial survival in planta, the immune systems of plants have also evolved to recognize the LPS structure and mount a basal defense response to counteract bacterial invasion (Newman et al. 2000). The LPS molecule is considered a pathogen-associated molecule pattern and elicits responses such as the oxidative burst, alterations in the plant cell wall, production of phytoalexins, a nitric oxide burst, and induction of pathogenesis-related proteins, among other plant defense-related responses (Madala et al. 2012; Newman et al. 2007; Silipo et al. 2005; Zeidler et al. 2004). $X$. fastidiosa is introduced by its insect vector directly into the xylem, a nonliving tissue, which cannot mount a defense response on its own. However, profound changes do occur in the adjacent living parenchyma cells upon infection, suggesting that these cells communicate with the xylem and are capable of recognizing the presence of a pathogen (Hilaire et al. 2001). The plant immune system can recognize several regions of the LPS structure, including the conserved lipid A and core oligosaccharide components (Newman et al. 2007; Silipo et al. 2005). Bacteria can also circumvent the host's immune system by altering the structure of their LPS molecule. Specifically, bacteria can display different $\mathrm{O}$-antigen profiles by varying the extent of polymerization or by completely abolishing synthesis of the O-antigen, depending on the environment and developmental phase of the cell (Bergman et al. 2006; Guerry et al. 2002; Lerouge and Vanderleyden 2002). We speculate that, during the interaction between $X$. fastidiosa and a susceptible grapevine host, the bacterium's rhamnose-rich O-antigen shields the conserved lipid A and core-oligosaccharide regions of the LPS molecule from being recognized by the grapevine immune system, providing an opportunity for it to subvert the basal defense response and establish itself in the host. A similar scenario occurs in Escherichia coli, where the long-chain O-antigen is important for serum resistance and truncation of the O-antigen caused an increased sensitivity to serum, suggesting that the full-length Oantigen provides a masking effect toward the host immune system (Guo et al. 2005). Salmonella enterica subsp. enterica sv. $(S$.) Typhimurium also possesses an O-antigen that aids in evasion of the murine immune system (Duerr et al. 2009).

The study we present here demonstrates the importance of Wzy in X. fastidiosa LPS biosynthesis as well as identifying it as a key contributor to virulence in a susceptible grapevine host. There is currently no cure for PD, which has caused significant economic loss to the wine, table, and raisin grape commodities in the United States. The findings in this study significantly advance the understanding of how $X$. fastidiosa interacts with the grapevine host and provide novel insight into the virulence mechanisms for this devastating agricultural pathogen which could have real implications in designing a successful PD control strategy. Pretreatment of plants with intact LPS from nonvirulent strains of pathogens can prime the defense systems of plants to protect against subsequent exposure to pathogens (Newman et al. 2007), which is an avenue worth exploring in the $X$. fastidiosa pathosystem.

\section{MATERIALS AND METHODS}

Bacterial strains, plasmids, and primers.

All bacterial strains, plasmids, and primers used in this study are listed in Table 4.

\section{Media and growth of bacterial strains.}

$X$. fastidiosa strains were grown at $28^{\circ} \mathrm{C}$ in PD3 broth and solid medium (Davis et al. 1981). E. coli strains were grown 
at $37^{\circ} \mathrm{C}$ in Luria-Bertani medium. When appropriate, kanamycin and chloramphenicol were added at $5 \mu \mathrm{g} / \mathrm{ml}$ for $X$. fastidiosa strains. For selection of $E$. coli transformants, spectinomycin and kanamycin were added at 100 and $30 \mu \mathrm{g} / \mathrm{ml}$, respectively.

\section{DNA manipulations.}

Standard molecular cloning techniques were utilized in this study (Sambrook and Russell 2001). X. fastidiosa genomic DNA was extracted using the DNeasy blood and tissue kit according to the manufacturer's instruction (Qiagen, Chatsworth, CA, U.S.A.). X. fastidiosa was transformed by electroporation, as previously described (Guilhabert et al. 2001), and E. coli was transformed as previously described (Sambrook and Russell 2001). Plasmid DNA isolation was performed using Zymo Research mini-prep kits (Zymo Research, Irvine, CA, U.S.A.). DNA sequencing was performed at the Institute for Integrative Biology (University of California, Riverside). Online tools used for DNA manipulation and DNA and protein analysis were Integrated Microbial Genomes, the National Center for Biotechnology Information, San Diego Supercomputer Center Biology Workbench, Netprimer, and SoftBerry.

\section{Mutagenesis and complementation.}

The primer pair wzyL 5'-GCGTGTAACCCCAAGATCAC$3^{\prime}$ and wzyR 5'-GTCCAAGGCTTTTAACTCGG-3' was used to amplify a 2.46-kb genomic DNA fragment, which was cloned into pCR8/GW/TOPO (Life Technologies, Grand Island, NY, U.S.A.) to create pJCC4. The Ez-Tn5 < kan-2> transposon was introduced into pJCC4 using the Ez-Tn5 in vitro transposome kit (Epicentre Technologies, Madison, WI, U.S.A.). Transformants were screened for antibiotic resistance and a plasmid with the $<\mathrm{kan}-2>$ cassette inserted into the cloned wzy gene was confirmed by polymerase chain reaction (PCR) amplification and sequence analysis to create pJCC6. To create the wzy mutant, $200 \mathrm{ng}$ of pJCC6 DNA was electroporated into competent $X$. fastidiosa Temecula1 cells, as previously described (Guilhabert et al. 2001). Transformants were plated on PD3 solid media amended with kanamycin at $5 \mu \mathrm{g} / \mathrm{ml}$. Genomic DNA was extracted from candidate mutants and confirmation of double recombination to replace the wild-type PD0814 with the disrupted version was performed by amplification of the regions to the left and right flank of the recombination site using primers wzykanflankR 5'-CACTCATCACCACGGCAT AC-3' with kan-RP-rev (5'-GCAATGTAACATCAGAGATTT TGAG-3'; Epicentre Technologies) and wzykanflankL 5'-TG ATGCTTCAAGACCGAACA-3' with kan-FP-for (5'-ACCTA CAACAAAGCTCTCATCAACC-3'; Epicentre Technologies), respectively.

For construction of the wzy/wzy+ complemented strain, a 1.84-kb genomic DNA fragment that included the wild-type wzy open reading frame and its upstream regulatory region was PCR amplified to include the addition of XbaI sites with primers wzyLcomp 5'-GAGGTGTCTAGATCAAGACCG-3' and wzyRcomp 5'-GGAGGATCTAGATTTCATCCG-3' and subcloned into $\mathrm{pCR} 8 / \mathrm{GW} / \mathrm{TOPO}$ to create pJCC7. The cloned fragment was excised with restriction enzyme $\mathrm{XbaI}$ and ligated into the $X b a \mathrm{I}$ site of the chromosomal complementation plasmid pAXCm1 (Matsumoto et al. 2009) to create pJCC8. To ensure sequence fidelity, the cloned region was sequenced. After transformation into electrocompetent $w z y$ mutant cells, the appropriate recombination between pJCC8 and the neutral chromosomal site between PD0702 and PD0703 was confirmed by using primers designed for the flanking region on either side of the site: PW-For 5'-AGAAGAGCGCGAGATT GAGTTGGA-3' and PW-Rev 5'-AAACAGGCTTCACATGG CTCAACG-3'.

\section{LPS extraction and analysis.}

LPS extractions were performed based on the method of Marolda and associates (2006) with some modification. Briefly, cells were harvested from plated cultures, adjusted to a final optical density at $600 \mathrm{~nm}\left(\mathrm{OD}_{600}\right)$ of $0.5 \mathrm{in} 1.5 \mathrm{ml}$ of $1 \times$ phosphate-buffered saline (PBS), washed, collected, and stored overnight at $-80^{\circ} \mathrm{C}$ prior to hot phenol treatment. The resulting LPS fraction was desalted using MicroSpin G-25 columns (GE Healthcare, Buckinghamshire, U.K.) (DeLoney et al. 2002). Then, $50 \mu \mathrm{l}$ was concentrated to dryness using a speed-vac (ThermoFisher Scientific, Asheville, NC, U.S.A.) and resuspended in $20 \mu \mathrm{l}$ of loading buffer, and $10 \mu \mathrm{l}$ of each sample was run on a $12 \%$ discontinuous Tricine-PAGE gel (Schägger 2006). To visualize the LPS profile, gels were silver stained according to the method of Tsai and Frasch (1982) with the following exception: LPS was oxidized with $1 \%$ periodic acid.

\section{$O$-antigen isolation and chemical analysis.}

Total LPS was isolated from $X$. fastidiosa cells as described above from at least five biological replicates per strain. The LPS preparations for each strain were pooled and O-antigen was isolated by mild acid hydrolysis in $1 \%$ acetic acid for $4 \mathrm{~h}$ at $100^{\circ} \mathrm{C}$, followed by centrifugation at $8,000 \mathrm{rpm}$ for $30 \mathrm{~min}$. The supernatant was removed and reserved for glycosyl composition and linkage analysis. Glycosyl composition analysis on the pooled samples was performed by combined gas chromatography and mass spectrometry (GC/MS) of the per- $O$-trimethylsilyl (TMS) derivatives of the monosaccharide methyl glycosides produced from the sample by acidic methanolysis, as previously described (Merkle and Poppe 1994). GC/MS analysis of the TMS methyl glycosides was performed on an Agilent 7890N GC interfaced to a 5975C MSD, using a Supelco EC-1 fused silica capillary column (30 by $0.25 \mathrm{~mm}$ interior diameter). For glycosyl linkage analysis, the sample was permethylated, depolymerized, reduced, and acetylated, and the resultant partially methylated alditol acetates was analyzed by GC/MS, as described by York and associates (1985).

\section{The zeta potential measurements.}

All bacterial strains were grown on solid PD3 medium for 7 days, harvested, washed once with $10 \mathrm{mM} \mathrm{KCl}$, and resuspended to a final $\mathrm{OD}_{600}=0.2$. in $10 \mathrm{mM} \mathrm{KCl}$. The electrophoretic mobility of the bacterial cells was determined at $25^{\circ} \mathrm{C}$ using a zeta potential analyzer (Brookhaven Instruments Corporation, Holtsville, NY, U.S.A.). The measurements were performed using two biological replicates for each strain, with five technical replicates for each biological replicate. Mobility values determined by electrophoresis were converted to zeta potential values, as previously described (O'Brien and White 1978). The average values for one representative experiment were reported here.

\section{Cell-surface attachment and cell-cell aggregation assays.}

$X$. fastidiosa strains were tested for their ability to attach to a glass surface according to a previously published protocol (Espinosa-Urgel et al. 2000). Briefly, X. fastidiosa strains were harvested from 7-day-old plates in PD3 liquid medium and the cell density was adjusted to an $\mathrm{OD}_{600}$ of 0.25 . Then, $500 \mu \mathrm{l}$ was added to $5 \mathrm{ml}$ of PD3 liquid medium in a $30-\mathrm{mm}$ glass tube and incubated at $28^{\circ} \mathrm{C}$ for 7 days at $100 \mathrm{rpm}$. Following this, the absorbance of the cell suspension was measured at $600 \mathrm{~nm}$. To quantify the extent of cell attachment, the cell suspension was removed and its absorbance was measured at 600 $\mathrm{nm}$. The tubes were then rinsed three times with deionized water. Following this, $500 \mu \mathrm{l}$ of filtered, $1 \%$ crystal violet stain was added and allowed to incubate for $20 \mathrm{~min}$. The crystal violet was removed and the tubes were rinsed three times with 
deionized water. The stained, attached cells were dissolved in $2 \mathrm{ml}$ of $95 \%$ ethanol and absorbance of the eluent was measured at $600 \mathrm{~nm}$. The attachment ratio was calculated by normalizing the $\mathrm{OD}_{600}$ of the crystal violet eluent to the $\mathrm{OD}_{600}$ of the cell suspension.

Using established protocols (Burdman et al. 2000; Guilhabert and Kirkpatrick 2005), we quantified the ability of cells to aggregate to one another. Briefly, X. fastidiosa strains were harvested, cell density adjusted, and prepared in glass tubes as described above. After 10 days of incubation without agitation, the cells were gently dispersed for $5 \mathrm{~s}$ using a low vortex speed and any formed aggregates were allowed to settle for $20 \mathrm{~min}$. The turbidity of the upper culture medium, consisting primarily of dispersed cells, was measured at an OD of 540 $\mathrm{nm}\left(\mathrm{OD}_{\mathrm{UC}}\right)$. This was returned to the original tube and the culture was homogenized using a hand-held, motorized pestle (Kontes; Kimberly Clark, Vineland, NJ, U.S.A.), after which the total cell density was measured $\left(\mathrm{OD}_{\mathrm{TC}}\right)$. The percentage of aggregated cells was calculated as $\left(\mathrm{OD}_{\mathrm{TC}}-\mathrm{OD}_{\mathrm{UC}}\right) / \mathrm{OD}_{\mathrm{TC}} \times 100$ (Burdman et al. 2000). A pairwise analysis of variance (ANOVA) was used to determine significance among the treatments for both the attachment and aggregation experiments.

\section{Biofilm formation.}

The three-dimensional biofilm architecture of $X$. fastidiosa wild-type, wzy, and wzy/wzy+ strains was assessed as previously described (Roper et al. 2007a). Briefly, X. fastidiosa was grown for 7 days on solid PD3 medium, harvested, and suspended in $1 \times$ PBS to a final $\mathrm{OD}_{600}=0.25$ (approximately $1 \times$ $\left.10^{8} \mathrm{CFU} / \mathrm{ml}\right)$. This cell suspension $(200 \mu \mathrm{l})$ was used to inoculate $20 \mathrm{ml}$ of liquid PD3 media in 50-ml Falcon tubes. An autoclaved glass microscope slide was placed vertically into each tube. Tubes were shaken for 2,4,6, and 8 days at $180 \mathrm{rpm}$ and $28^{\circ} \mathrm{C}$, allowing $X$. fastidiosa biofilms to form at the air-liquid interface on the microscope slide. At each time point, slides were removed and gently heat fixed. Slides were stained with the nucleic acid stain Syto 9 (Invitrogen, Carlsbad, CA, U.S.A.), mounted in Slowfade mounting fluid (Invitrogen), and immediately imaged using a Zeiss 510 confocal laser-scanning microscope. Biofilms were observed using a $60 \times$ C-Apochromat water immersion lens (numerical aperture, 1.2). Syto 9 was excited using the 488-nm laser. $X$. fastidiosa biofilms were imaged through the $z$ axis, with $\mathrm{z}$-sections equaling $0.2 \mu \mathrm{m}$. Images were processed using Image $\mathbf{J}$ software. Each biofilm experiment contained three biological reps with three technical reps. At least eight images were taken at different places for each replicate biofilm. Each experiment was repeated at three independent times. For the biofilm thickness measurements, we used Bitplane software to measure these values, determined at 10 fixed locations along each section. Orthogonal sections were created on the $y z$ axis and biofilm thickness was determined as the distance between the glass surface and the biofilm-liquid interface (Grade et al. 2011). Measurements were taken at 10 fixed positions along the section. A Student's $t$ test was used to determine significance between the treatments.

\section{Disk inhibition assay.}

$X$. fastidiosa strains were tested for their ability to tolerate oxidative stress in the form of exogenously applied $\mathrm{H}_{2} \mathrm{O}_{2}$ according to the method of Matsumoto and associates (2009). Briefly, cells were harvested in PD3 broth from solid PD3 medium after 7 days of incubation, adjusted to an $\mathrm{OD}_{600}$ of 0.25 in PD3 broth, diluted 1:10 in $3 \mathrm{ml}$ of PD3 with $0.8 \%$ agar, and overlaid onto solid PD3 medium. A paper disk saturated with $10 \mu \mathrm{l}$ of $100 \mu \mathrm{M} \mathrm{H}_{2} \mathrm{O}_{2}$ was placed in the center of the plate. After 7 days of incubation at $28^{\circ} \mathrm{C}$, the zone of inhibition created by the bacterium's susceptibility to the peroxide was measured. Three independent assays with triplicate measurements were performed per strain. A pairwise ANOVA was used to determine significance among the different treatments.

\section{Pathogenicity assays and xylem colonization.}

Grapevines were mechanically inoculated using the pinprick method originally described by Hill and Purcell (1995). Cells of $X$. fastidiosa strains were harvested from PD3 medium in $1 \times$ PBS and cell density was determined by measuring turbidity at an OD of $600 \mathrm{~nm}$. Each suspension was adjusted to an OD of 0.25 at $600 \mathrm{~nm}$, which is equivalent to $1 \times 10^{8}$ $\mathrm{CFU} / \mathrm{ml}$. Each vine was inoculated twice above the first node on the stem with a $20-\mu l$ drop. Three independent trials of 10 plants each were used. Grapevines were rated weekly for PD symptom development for 17 weeks after inoculation using a disease scale of 0 to 5 (Guilhabert and Kirkpatrick 2005), where $0=$ no PD symptoms, $1=$ one or two leaves just beginning to show marginal necrosis, $2=$ two to three leaves with significant marginal necrosis, $3=$ one-half or more of the leaves showing marginal necrosis and a few match sticks (attached petioles whose leaf blade had abscised), $4=$ all of the leaves showing heavy scorching and numerous matchsticks, and $5=$ a dead vine.. To determine the extent to which the LPS moiety is a virulence factor for $X$. fastidiosa, we quantified wild-type and wzy mutant populations per gram of tissue by isolating cells from the first intact petiole closest to the point of inoculation. Isolations were performed twice: at 5 and 14 weeks postinoculation. Petioles were surface sterilized (1 min in $95 \%$ ethanol, $2 \mathrm{~min}$ in $20 \%$ bleach, and twice for $2 \mathrm{~min}$ in sterile deionized water) and ground in $2 \mathrm{ml}$ of sterile $1 \times$ PBS. The resulting suspension was diluted and plated on solid PD3 medium according to standard methods. A Wilcoxon rank sums test was used to determine significance among the treatments.

\section{ACKNOWLEDGMENTS}

This study was supported by a research grant received from the United States Department of Agriculture Cooperative State Research, Education and Extension Service University of California Pierce's Disease Grant Program and the California Department of Food and Agriculture Pierce's Disease and Glassy-Winged Sharpshooter Board. This study was also supported, in part, by the Department of Energy-funded (DE-FG02-93ER20097) Center for Plant and Microbial Complex Carbohydrates. We thank $\mathrm{K}$. Xu for assistance with the statistical analysis, S. Walker and I. Marcus for assistance with zeta potential analysis, H. Azad for helpful discussions, B. Kirkpatrick and D. Cooksey for providing bacterial strains, and M. Igo for providing the $\mathrm{pAX} 1$ series complementation vectors.

\section{LITERATURE CITED}

Abarca-Grau, A. M., Burbank, L. P., de Paz, H. D., Crespo-Rivas, J. C., Marco-Noales, E., Lopez, M. M., Vinardell, J. M., von Bodman, S. B., and Penyalvera, R. 2012. Role for Rhizobium rhizogenes K84 Cell Envelope Polysaccharides in Surface Interactions. Appl. Environ. Microbiol. 78:1644-1651.

Apel, K., and Hirt, H. 2004. Reactive oxygen species: Metabolism, oxidative stress, and signal transduction. Annu. Rev. Plant Biol. 55:373-399.

Bergman, M., Del Prete, G., van Kooyk, Y., and Appelmelk, B. 2006. Helicobacter pylori phase variation, immune modulation and gastric autoimmunity. Nat. Rev. Microbiol. 4:151-159.

Berry, M. C., McGhee, G. C., Zhao, Y. F., and Sundin, G. W. 2009. Effect of a waaL mutation on lipopolysaccharide composition, oxidative stress survival, and virulence in Erwinia amylovora. FEMS (Fed. Eur. Microbiol. Soc.) Mircobiol. Lett. 291:80-87.

Bogdanove, A. J., Koebnik, R., Lu, H., Furutani, A., Angiuoli, S. V., Patil, P. B., Van Sluys, M. A., Ryan, R. P., Meyer, D. F., Han, S. W., Aparna, G., Rajaram, M., Delcher, A. L., Phillippy, A. M., Puiu, D., Schatz, M. C., Shumway, M., Sommer, D. D., Trapnell, C., Benahmed, F., Dimitrov, G., Madupu, R., Radune, D., Sullivan, S., Jha, G., Ishihara, H., Lee, S. W., Pandey, A., Sharma, V., Sriariyanun, M., Szurek, B., Vera-Cruz, C. M., Dorman, K. S., Ronald, P. C., Verdier, V., Dow, J. M., Sonti, R. V., Tsuge, S., Brendel, V. P., Rabinowicz, P. D., Leach, J. E., White, F. F., 
and Salzberg, S. L. 2011. Two new complete genome sequences offer insight into host and tissue specificity of plant pathogenic Xanthomonas spp. J. Bacteriol. 193:5450-5464.

Burdman, S., Jurkevitch, E., Soria-Díaz, M. E., Gil Serrano, A. M., and Okon, Y. 2000. Extracellular polysaccharide composition of Azospirillum brasilense and its relation with cell aggregation. FEMS (Fed. Eur. Microbiol. Soc.) Microbiol. Lett. 189:259-264.

Caroff, M., and Karibian, D. 2003. Structure of bacterial lipopolysaccharides. Carbohydr. Res. 338:2431-2447.

Casabuono, A., Petrocelli, S., Ottado, J., Orellano, E. G., and Couto, A. S 2011. Structural analysis and involvement in plant innate immunity of Xanthomonas axonopodis pv. citri lipopolysaccharide. J. Biol. Chem. 286:25628-25643.

Caserta, R., Takita, M. A., Targon, M. L., Rosselli-Murai, L. K., de Souza, A. P., Peroni, L., Stach-Machado, D. R., Andrade, A., Labate, C. A. Kitajima, E. W., Machado, M. A., and de Souza, A. A. 2010. Expression of Xylella fastidiosa fimbrial and afimbrial proteins during biofilm formation. Appl. Environ. Microbiol. 76:4250-4259.

Chatterjee, S., Almeida, R. P. P., and Lindow, S. 2008. Living in two worlds: The plant and insect lifestyles of Xylella fastidiosa. Annu. Rev. Phytopathol. 46:243-271.

Davis, M. J., French, W. J., and Schaad, N. W. 1981. Axenic culture of the bacteria associated with phony disease of peach and plum leaf scald. Curr. Microbiol. 6:309-314

De La Fuente, L., Burr, T. J., and Hoch, H. C. 2008. Autoaggregation of Xylella fastidiosa cells is influenced by type I and type IV pili. Appl. Environ. Microbiol. 74:5579-5582.

DeLoney, C. R., Bartley, T. M., and Visick, K. 2002. Role for phosphoglucomutase in Vibrio fischeri-Euprymna scolopes symbiosis. J. Bacteriol. 184:5121-5129.

Dow, J. M., Osbourn, A. E., Wilson, T. J. G., and Daniels, M. J. 1995. A Locus Determining pathogenicity of Xanthomonas campestris is involved in lipopolysaccharide biosynthesis. Mol. Plant-Microbe Interact. 8:768-777

Duerr, C. U., Zenk, S. F., Chassin, C., Pott, J., Gutle, D., Hensel, M., and Hornef, M. W. 2009. O-Antigen delays lipopolysaccharide recognition and impairs antibacterial host defense in murine intestinal epithelial cells. PLoS Pathog. 5:e1000567. Published online.

Espinosa-Urgel, M., Salido, A., and Ramos, J.-L. 2000. Genetic analysis of functions involved in adhesion of Pseudomonas putida to seeds. J. Bacteriol. 182:2363-2369.

Feil, H., Feil, W. S., and Lindow, S. E. 2007. Contribution of fimbrial and afimbrial adhesins of Xylella fastidiosa to attachment to surfaces and virulence to grape. Phytopathology 97:318-324.

Foppen, J. W., Lutterodt, G., Roling, W. F. M., and Uhlenbrook, S. 2010. Towards understanding inter-strain attachment variations of Escherichia coli during transport in saturated quartz sand. Water Res. 44:1202-1212.

Goldberg, J. B., and Pler, G. B. 1996. Pseudomonas aeruginosa lipopolysaccharides and pathogenesis. Trends Microbiol. 4:490-494.

Grade, S., Wieland, H., Strempel, J., and Stiesch, M. 2011. Structural analysis of in situ biofilm formation on titanium implants. J. Dental Implants 1:7-12.

Guerry, P., Szymanski, C. M., Prendergast, M. M., Hickey, T. E., Ewing, C. P., Pattarini, D. L., and Moran, A. P. 2002. Phase variation of Campylobacter jejuni 81-176 lipooligosaccharide affects ganglioside mimicry and invasiveness in vitro. Infect. Immun. 70:787-793.

Guilhabert, M. R., and Kirkpatrick, B. C. 2005. Identification of Xylella fastidiosa antivirulence genes: Hemagglutinin adhesins contribute to $X$. fastidiosa biofilm maturation and colonization and attenuate virulence. Mol. Plant-Microbe Interact. 18:856-868

Guilhabert, M. R. L., Hoffman, L. M., Mills, D. A., and Kirkpatrick, B. C. 2001. Transposon mutagenesis of Xylella fastidiosa by electroporation of Tn5 synaptic complexes. Mol. Plant-Microbe Interact. 14:701-706.

Guo, H. J., Yi, W., Shao, J., Lu, Y. Q., Zhang, W. P., Song, J., and Wang, P. G. 2005. Molecular analysis of the O-antigen gene cluster of Escherichia coli $\mathrm{O} 86$ : $\mathrm{B} 7$ and characterization of the chain length determinant gene (wzz). Appl. Environ. Microbiol. 71:7995-8001.

Hendrick, C. A., and Sequeira, L. 1984. Lipopolysaccharide defective mutants of the wilt pathogen Pseudomonas solanacearum. Appl. Environ. Microbiol. 48:94-101.

Hilaire, E., Young, S. A., Willard, L. H., McGee, J. D., Sweat, T., Chittoor, J. M., Guikema, J. A., and Leach, J. E. 2001. Vascular defense responses in rice: Peroxidase accumulation in xylem parenchyma cells and xylem wall thickening. Mol. Plant-Microbe Interact. 14:1411-1419.

Hill, B. L., and Purcell, A. H. 1995. Acquisition and retention of Xylella fastidiosa by an efficient vector, Graphocephala atropunctata. Phytopathology 85:209-212.

Huang, T. P., Somers, E. B., and Wong, A. C. L. 2006. Differential biofilm formation and motility associated with lipopolysaccharide/exopolysac- charide-coupled biosynthetic genes in Stenotrophomonas maltophilia. J. Bacteriol. 188:3116-3120.

Islam, S. T., Taylor, V. L., Qi, M., and Lam, J. S. 2010. Membrane topology mapping of the O-antigen flippase (Wzx), polymerase (Wzy), and Ligase (WaaL) from Pseudomonas aeruginosa PAO1 reveals novel domain architectures. mBio 1:e00189-00110.

Ivanov, I. E., Kintz, E. N., Porter, L. A., Goldberg, J. B., Burnham, N. A., and Camesano, T. A. 2011. Relating the Physical Properties of Pseudomonas aeruginosa lipopolysaccharides to virulence by atomic force microscopy. J. Bacteriol. 193:1259-1266.

Janse, J. D., and Obradaovic, A. 2010. Xylella fastidiosa: Its biology, diagnosis, control and risks. J. Plant Pathol. 92:S1.35-S31.48.

Karatan, E., and Watnick, P. 2009. Signals, regulatory networks, and materials that build and break bacterial biofilms. Microbiol. Mol. Biol. R 73:310-347.

Kastowsky, M., Gutberlet, T., and Bradaczek, H. 1992. Molecular Modeling of the 3-Dimensional Structure and Conformational Flexibility of Bacterial Lipopolysaccharide. J. Bacteriol. 174:4798-4806.

Killiny, N., and Almeida, R. P. P. 2009. Xylella fastidiosa afimbrial adhesins mediate cell transmission to plants by leafhopper vectors. Appl. Environ. Microbiol. 75:521-528.

Kim, T. H., Pinkham, J. T., Heninger, S. J., Chalabaev, S., and Kasper, D. L. 2012. Genetic modification of the O-polysaccharide of Francisella tularensis results in an avirulent live attenuated vaccine. J. Infect. Dis. 205:1056-1065.

Koplin, R., Wang, G., Hotte, B., Priefer, U. B., and Puhler, A. 1993. A 3.9$\mathrm{Kb}$ DNA Region of Xanthomonas campestris pv. campestris that is necessary for lipopolysaccharide production encodes a set of enzymes involved in the synthesis of Dtdp-Rhamnose. J. Bacteriol. 175:77867792.

Kotra, L. P., Golemi, D., Amro, N. A., Liu, G. Y., and Mobashery, S. 1999. Dynamics of the lipopolysaccharide assembly on the surface of Escherichia coli. J. Am. Chem. Soc. 121:8707-8711.

Lamb, C., and Dixon, R. A. 1997. The oxidative burst in plant disease resistance. Annu. Rev. Plant Physiol. Plant Mol. Biol. 48:251-275.

Lau, P. C. Y., Lindhout, T., Beveridge, T. J., Dutcher, J. R., and Lam, J. S. 2009. Differential lipopolysaccharide core capping leads to quantitative and correlated modifications of mechanical and structural properties in Pseudomonas aeruginosa biofilms. J. Bacteriol. 191:6618-6631.

Lerouge, I., and Vanderleyden, J. 2002. O-antigen structural variation: Mechanisms and possible roles in animal/plant-microbe interactions. FEMS (Fed. Eur. Microbiol. Soc.) Microbiol. Rev. 26:17-47.

Li, J., and Wang, N. 2011. The wxacO gene of Xanthomonas citri ssp. citri encodes a protein with a role in lipopolysaccharide biosynthesis, biofilm formation, stress tolerance and virulence. Mol. Plant Pathol. 12:381-396.

Li, Y. X., Hao, G. X., Galvani, C. D., Meng, Y. Z., De la Fuente, L., Hoch, H. C., and Burr, T. J. 2007. Type I and type IV pili of Xylella fastidiosa affect twitching motility, biofilm formation and cell-cell aggregation. Microbiology 153:719-726.

Madala, N. E., Molinaro, A., and Dubery, I. A. 2012. Distinct carbohydrate and lipid-based molecular patterns within lipopolysaccharides from Burkholderia cepacia contribute to defense-associated differential gene expression in Arabidopsis thaliana. Innate Immun. 18:140-154.

Madigan, M. T. 2012. Brock Biology of Microorganisms. Benjamin Cummings, San Francisco.

Marolda, C. L., Lahiry, P., Vinés, E., Salidías, S., and Valvano, M. A. 2006. Micromethods for the characterization of lipid A-core and O-antigen lipopolysaccharide. In: Methods in Molecular Biology. I. Brockhausen, ed. Humana Press, Inc., Totowa, NJ, U.S.A.

Matsumoto, A., Young, G. M., and Igo, M. M. 2009. Chromosome-based complementation system for Xylella fastidiosa. Appl. Environ. Microbiol. 75:1679-1687.

Merkle, R. K., and Poppe, I. 1994. Carbohydrate composition analysis of glycoconjugates by gas-liquid chromatography mass-spectrometry. Guide Tech. Glycobiol. 230:1-15.

Molinaro, A., De Castro, C., Lanzetta, R., Parrilli, M., Petersen, B. O. Broberg, A., and Duus, J. O. 2002. NMR and MS evidences for a random assembled O-specific chain structure in the LPS of the bacterium Xanthomonas campestris pv. vitians - a case of unsystematic biosynthetic polymerization. Eur. J. Biochem. 269:4185-4193.

Monds, R. D., and O'Toole, G. A. 2009. The developmental model of microbial biofilms: Ten years of a paradigm up for review. Trends Microbiol. 17:73-87.

Muhldorfer, I., and Hacker, J. 1994. Genetic aspects of Escherichia coli virulence. Microb. Pathog. 16:171-181.

Murga, R., Stewart, P. S., and Daly, D. 1995. Quantitative analysis of biofilm thickness variability. Biotechnol. Bioeng. 45:503-510.

Nakhamchik, A., Wilde, C., and Rowe-Magnus, D. A. 2007. Identification of a wzy polymerase required for group IV capsular polysaccharide and 
lipopolysaccharide biosynthesis in Vibrio vulnificus. Infect. Immun. 75:5550-5558.

Newman, K. L., Almeida, R. P. P., Purcell, A. H., and Lindow, S. E. 2004 Cell-cell signaling controls Xylella fastidiosa interactions with both insects and plants. Proc. Natl. Acad. Sci. U.S.A. 101:1737-1742.

Newman, M. A., Von Roepenack, E., Daniels, M., and Dow, M. 2000. Lipopolysaccharides and plant responses to phytopathogenic bacteria. Mol. Plant Pathol. 1:25-31.

Newman, M. A., Dow, J. M., Molinaro, A., and Parrilli, M. 2007. Priming, induction and modulation of plant defence responses by bacterial lipopolysaccharides. J. Endotoxin Res. 13:69-84.

O'Brien, R. W. and White, L. R. 1978. Electrophoretic mobility of a spherical colloidal particle. J. Chem. Soc. Faraday Trans. 2 74:1607.

O'Toole, G., Kaplan, H. B., and Kolter, R. 2000. Biofilm formation as microbial development. Annu. Rev. Microbiol. 54:49-79.

Piciorneanu, C. van Loosdrecht, M. C. M., and Heijnen, J. J. 2000. A theoretical study on the effect of surface roughness on mass transport and transformation in biofilms. Biotechnol. Bioeng. 68:355-369.

Petrocelli, S., Tondo, M. L., Daurelio, L. D., and Orellano, E. G. 2012. Modifications of Xanthomonas axonopodis pv. citri lipopolysaccharide affect the basal response and the virulence process during citrus canker. PLoS One 7:e40051. Published online.

Raetz, C. R. H., and Whitfield, C. 2002. Lipopolysaccharide endotoxins. Annu. Rev. Biochem. 71:635-700.

Roper, M. C., Greve, L. C., Labavitch, J. A., and Kirkpatrick, B. C. 2007a Detection and visualization of an exopolysaccharide produced by Xylella fastidiosa in vitro and in planta. Appl. Environ. Microbiol. 73:7252-7258.

Roper, M. C., Greve, L. C., Warren, J. G., Labavitch, J. M., and Kirkpatrick, B. C. 2007b. Xylella fastidiosa requires polygalacturonase for colonization and pathogenicity in Vitis vinifera grapevines. Mol. Plant-Microbe Interact. 20:411-419.

Rost, B., Yachdav, G., and Liu, J. 2003. The PredictProtein Server. Nucleic Acids Res. 32:W321-W326.

Sambrook, J., and Russell, D. W. 2001. Molecular Cloning: A Laboratory Manual, 3rd ed. Cold Spring Harbor Laboratory Press, Cold Spring Harbor, NY, U.S.A.

Schägger, H. 2006. Tricine-SDS-PAGE. Nat. Prot. 1:16-22.

Shashkov, A. S., Senchenkova, S. N., Laux, P., Ahohuendo, B. C., Kecskes, M. L., Rudolph, K., and Knirel, Y. A. 2000. Structure of the O-chain polysaccharide of the lipopolysaccharide of Xanthomonas campestris pv. manihotis GSPB 2755 and GSPB 2364. Carbohydr. Res. 323:235-239.

Silipo, A., Molinaro, A., Sturiale, L., Dow, J. M., Erbs, G., Lanzetta, R., Newman, M. A., and Parrilli, M. 2005. The elicitation of plant innate immunity by lipooligosaccharide of Xanthomonas campestris. J. Biol. Chem. 280:33660-33668.

Tsai, C.-M., and Frasch, C. E. 1982. A sensitive silver stain for detecting lipopolysaccharides in polyacrylamide gels. Anal. Biochem. 119:115-119.

Tibbits, C. W., MacDougall, A. J., and Ring, S. G. 1998. Calcium binding and swelling behaviour of a high methoxyl pectin gel. Carbohydr. Res.
310:101-107.

Valvano, M. A. 2003. Export of O-specific lipopolysaccharide. Front Biosci. 8:s452-471.

Vanloosdrecht, M. C. M., Lyklema, J., Norde, W., Schraa, G., and Zehnder, A. J. B. 1987. Electrophoretic mobility and hydrophobicity as a measure to predict the initial steps of bacterial adhesion. Appl. Environ. Microbiol. 53:1898-1901.

Varela, L., Smith, R., and Philips, P. 2001. Pierce's Disease. Univ. Calif. Agric. Nat. Resour. Publ. 21600, Oakland.

Walker, S. L., Redman, J. A., and Elimelech, M. 2004. Role of cell surface lipopolysaccharides in Escherichia coli K12 adhesion and transport. Langmuir 20L7736-7746.

Wang, X., and Quinn, P. J. 2010. Lipopolysaccharide: Biosynthetic pathway and structure modification. Prog. Lipid Res. 49:97-107.

Whitfield, C. 1995. Biosynthesis of lipopolysaccharide O antigens. Trends Microbiol. 3:178-185.

Whitfield, C., and Larue, K. 2008. Stop and go: Regulation of chain length in the biosynthesis of bacterial polysaccharides. Nat. Struct. Mol. Biol. 15:121-123.

Wilson, W. W., Wade, M. M., Holman, S. C., and Champlin, F. R. 2001 Status of methods for assessing bacterial cell surface charge properties based on zeta potential measurements. J. Microbiol. Methods 43:153164.

Yan, Q., Hu, X., and Wang, N. 2012. The novel virulence-related gene $n l x A$ in the lipopolysaccharide cluster of Xanthomonas citri ssp. citri is involved in the production of lipopolysaccharide and extracellular polysaccharide, motility, biofilm formation and stress resistance. Mol. Plant Pathol. 13:923-934

York, W. S. D., Darvill, A., McNeil, M., and Albersheim, P. 1985. Isolation and characterization of plant cell walls and cell-wall components. Methods Enzymol. 118:3-40.

Zeidler, D., Zahringer, U., Gerber, I., Dubery, I., Hartung, T., Bors, W., Hutzler, P., and Durner, J. 2004. Innate immunity in Arabidopsis thaliana: Lipopolysaccharides activate nitric oxide synthase (NOS) and induce defense genes. Proc. Natl. Acad. Sci. U.S.A. 101:15811-15816.

Zwieniecki, M. A., Melcher, P. J, and Holbrook, N. M. 2001. Hydrogel control of xylem hydraulic resistance in plants. Science 291:1059-1062.

\section{AUTHOR-RECOMMENDED INTERNET RESOURCES}

Colorado State University hydropathy plot analysis webpage: www.vivo.colostate.edu/molkit/hydropathy/index.html

Joint Genome Institute Integrated Microbial Genomes (IMG 4) data management software: img.jgi.doe.gov

National Center for Biotechnology Informationwebsite: www.ncbi.nlm.nih.gov

Premier Biosoft Netprimer software: www.premierbiosoft.com

San Diego Supercomputer Center (SDSC) Biology Workbench: www.workbench.sdsc.edu

SoftBerrysoftware: linux1.softberry.com 